\title{
Eicosanoid mediator expression in mononuclear and polymorphonuclear cells in normal subjects and patients with atopic asthma and cystic fibrosis
}

\author{
L M Kuitert, R Newton, N C Barnes, I M Adcock, P J Barnes
}

\begin{abstract}
Background - Eicosanoids such as leukotrienes, prostaglandins, lipoxins, and 15-hydroperoxyeicosatetraenoic acid (15HETE) cause bronchoconstriction, increased microvascular permeability, mucus secretion, and polymorph chemotaxis. These pro-inflammatory effects are important in diseases such as asthma and cystic fibrosis where the levels of mediators are increased both in the stable and acute state. A study was conducted to examine the expression of the mRNA for the enzymes of the eicosanoid pathways (5-lipoxygenase (5-LO), 5-lipoxygenase activating protein (FLAP), cyclo-oxygenases 1 and 2 (COX-1, COX-2), and 15lipoxygenase (15-LO)) in normal subjects and in patients with stable atopic asthma and stable cystic fibrosis.
\end{abstract}

Methods - Reverse transcription polymerase chain reaction (RT-PCR) was used to examine the expression of total RNA for 5-LO, FLAP, COX-1, COX-2, and 15-LO in peripheral blood polymorphonuclear cells and mononuclear cells from the three subject groups.

Results - The expression of mRNA for 5-LO and FLAP was similar in normal subjects and in patients with asthma and cystic fibrosis. COX-1 was increased in both cell types in asthmatic patients. COX-2 and 15-LO were increased in polymorphs of patients with atopic asthma but not in mononuclear cells. COX-2 and 15LO were undetectable in either cell type in patients with cystic fibrosis whereas COX-1 levels in polymorphs were similar to those in patients with asthma.

Conclusions - The increased leukotriene production in asthma and cystic fibrosis is not explained by an increase in transcription of 5-LO and FLAP. Transcription of 15-LO and COX-2 is increased in atopic asthma. Transcription of COX-1 is increased in both atopic asthma and cystic fibrosis.

(Thorax 1996;51:1223-1228)

Keywords: asthma, cystic fibrosis, eicosanoids, leukotrienes.

The eicosanoids, a group of mediators implicated in the inflammatory response, are the product of the metabolism of arachidonic acid by three separate enzymes. The enzyme 5-lipoxygenase (5-LO), together with 5-lipoxygenase activating protein (FLAP), results in the formation of the leukotrienes; the two isoforms of cyclo-oxygenase, COX-1 and COX-2, in the formation of prostaglandins, prostacyclin and thromboxane; and 15-lipoxygenase (15-LO) in the formation of 15-hydroperoxyeicosatetraenoic acid (15HETE) and the lipoxins. The leukotrienes are pro-inflammatory, causing polymorphonuclear cell chemotaxis, bronchoconstriction, increased mucus secretion, and increased vascular permeability. ${ }^{12}$ Individual prostaglandins have opposing activities. Prostaglandins formed by COX-1 are responsible for the maintenance of cellular function whereas the inducible COX-2 is responsible for production of the pro-inflammatory prostaglandins. ${ }^{34}$ The products of 15-LO are interesting in that they are anti-inflammatory. They antagonise the effects of the leukotrienes, inhibit free radical production, and inhibit receptor-mediated cellular activation. ${ }^{5-8}$

Eicosanoids are important in inflammatory diseases such as asthma and cystic fibrosis. Increased levels of leukotrienes have been demonstrated in both stable asthma and during acute exacerbations, ${ }^{9-11}$ and both the prostaglandins and lipoxin $\mathrm{A}_{4}$ have been found in a number of pulmonary diseases including asthma. ${ }^{912}$ Furthermore, inhibition of leukotriene production improves asthma. ${ }^{13}$

Despite the evidence of increased eicosanoid mediator levels in asthma and cystic fibrosis, to our knowledge there has been no investigation into the regulation of eicosanoid production in these patient groups. We have used a semi-quantitative reverse transcriptionpolymerase chain reaction (RT-PCR) approach to examine the expression of the mRNA for 5LO and FLAP, COX-1, COX-2, and 15-LO in peripheral blood mononuclear cells and polymorphonuclear cells of normal subjects and patients with stable atopic asthma and stable cystic fibrosis.

\section{Methods}

MATERIALS

All chemicals were of molecular biology grade and purchased from Sigma (Poole, UK). Ficoll Paque was purchased from Pharmacia (St Albans, UK). RT-PCR components were purchased from Promega except for Taq DNA polymerase (Boehringer Mannheim, Lewes, UK). Primers were synthesised by R \& D Systems, Abingdon, UK. 


\begin{tabular}{|c|c|c|}
\hline Primer & Sequence & $\begin{array}{l}\text { Expected } \\
\text { size }\end{array}$ \\
\hline GAPDH & $\begin{array}{l}\text { F 5'-TTC CAT GGC ACC GTC AAG GCT } \\
\text { R 5'-TCA GGT CCA CCA CTG ACA CGT T }\end{array}$ & 468 \\
\hline COX-1 & $\begin{array}{l}\text { F 5'-TGC CCA GCT GGC CCG CCG CTT } \\
\text { R 5'-GTG CAT CAA CAC AGG CGC CTC TTC }\end{array}$ & 301 \\
\hline COX-2 & $\begin{array}{l}\text { F 5'-TTC AAA TGA GAT TGT GGG AAA ATT GCT } \\
\text { R 5'-AGA TCA TCT CTG CCT GAG TAT CTT }\end{array}$ & 304 \\
\hline 5-LO & $\begin{array}{l}\text { F 5'-ATC AGG ACG TTC ACG GCC GAG G } \\
\text { R 5'-CCA GGA ACA GCT CGT TTT CCT G }\end{array}$ & 300 \\
\hline FLAP & $\begin{array}{l}\text { F 5'-GGC AAT GTT GTC CTG CTG TTG GCC } \\
\text { R 5'-GCG TTC TCT CTC CTA GGT AAC }\end{array}$ & 350 \\
\hline 15-LO & $\begin{array}{l}\text { F 5'-GTT CCA ACA ACC AGG TGC AGC } \\
\text { R 5'-GCT CTT CTT CCC GGT GTT TCT }\end{array}$ & 447 \\
\hline \multicolumn{3}{|c|}{$\begin{array}{l}\text { Figure } 1 \text { Primer sequences for the genes of interest. } G A P D H=\text { glyceraldehyde phosphate } \\
\text { dehydrogenase; } C O X-1=\text { cyclo-oxygenase } 1 ; C O X-2=\text { cyclo-oxygenase } 2 ; 5-L O=5- \\
\text { lipoxygenase; FLAP=5-lipoxygenase activating protein; } 15-L O=15 \text {-lipoxygenase. } \\
\\
\text { PATIENTs } \\
\text { The study was approved by the ethics com- } \\
\text { mittee of the Royal Brompton, National Heart } \\
\text { and Lung Hospitals. All subjects gave informed } \\
\text { consent. Normal subjects were volunteers who } \\
\text { gave a negative history for atopy and had a } \\
\text { normal peripheral blood eosinophil count and } \\
\text { total IgE count. Atopic asthmatic patients had } \\
\text { asthma as defined by the American Thoracic } \\
\text { Society and were stable on inhaled } \beta_{2} \text { agonists } \\
\text { and inhaled corticosteroids in doses of less than } \\
\text { 1200 } \mu \text { g/day. All had a positive history for atopy } \\
\text { (eczema or hayfever) and an elevated total IgE } \\
\text { count. Some also had a mild peripheral blood } \\
\text { eosinophilia. Patients with cystic fibrosis were } \\
\text { attending the outpatients department of the } \\
\text { London Chest Hospital; they had had no in- } \\
\text { fective exacerbations for the previous six weeks } \\
\text { and were taking no inhaled or oral cortico- } \\
\text { steroids. Their only other treatments were vit- } \\
\text { amin E and pancreatic enzyme supplements. }\end{array}$} \\
\hline
\end{tabular}

CELL SEPARATION

Fifty $\mathrm{ml}$ of venous blood was collected into a syringe containing $8 \mathrm{ml}$ of acid citrate dextran (ACD), immediately placed on ice, and all subsequent steps performed at $4^{\circ} \mathrm{C}$ to minimise activation of the cells. The white blood cells were separated by density gradient centrifugation using Ficoll Paque. The resulting mononuclear cell and polymorphonuclear cell layers were removed and washed with 2-4 volumes of cold Hank's Balanced Salt Solution (HBSS) without calcium or magnesium. Cells were resuspended in $1 \mathrm{ml}$ of cold HBSS, an aliquot was removed, and cell numbers were counted and purity assessed on a haemocytometer. In all subsequent steps the preparations were more than $98 \%$ pure.

RNA ISOLATION

The RNA was extracted according to the method of Gough ${ }^{14}$ in the presence of RNAse
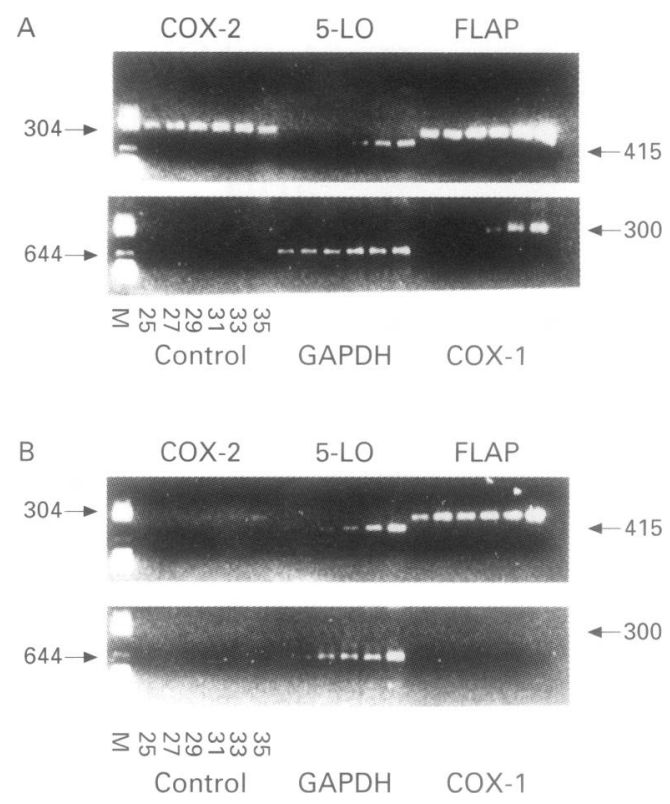

Figure 2 Detection of $1 \mu \mathrm{g}$ of $m R N A$ by $R T-P C R$ in normal and asthmatic subjects. (A) Analysis of PCR product detected after increasing cycles of $P C R$ in polymorphonuclear cells from an atopic asthmatic subject. The result is representative of 15 experiments. (B) As for (A) but for a normal subject. The result is representative of eight experiments. 15-LO was negative for each of these subjects. $M=D N A$ size markers.

inhibitors. The RNA was washed twice in ethanol and precipitated, and the amount of total RNA quantified by spectrophotometry at $260 \mathrm{~nm}$ (Uvikon 940 Spectrophotometer, Kontron, Zurich, Switzerland).

\section{REVERSE TRANSCRIPTION-POLYMERASE CHAIN} REACTION (RT-PCR)

One $\mu \mathrm{g}$ of total RNA was reverse transcribed into cDNA with AMV reverse transcriptase and oligo $(\mathrm{dT})_{15}$ primers according to standard protocols (Promega, Southampton, UK).

PCR was performed on the resulting $\mathrm{CDNA}$ using specific primers for COX-1, COX-2, 5-LO, FLAP, 15-LO, and glyceraldehyde 3phosphate dehydrogenase (GAPDH) (fig 1) using Taq polymerase according to the manufacturer's instructions. Up to 35 cycles were performed $\left(95^{\circ} \mathrm{C}, 1\right.$ minute; $60^{\circ} \mathrm{C}, 1$ minute; $72^{\circ} \mathrm{C}, 1$ minute) for all primer sets except $15-$ LO (annealing temperature $63^{\circ} \mathrm{C}$ ). GAPDH was used as a positive control for the PCR reaction and a no template cDNA control as the negative control. Aliquots $(8 \mu \mathrm{l})$ were removed at $25,27,29,31,33$ and 35 cycles, size fractionated on a $2 \%$ agarose gel, and the cycle number at which the correct product first appeared determined (fig $2 \mathrm{~A}$ and $\mathrm{B}$ ).

\section{SEMI-QUANTITATION OF PCR PRODUCTS}

The PCR products were cloned into pGEM5z vectors and the product sequenced to confirm identity. For further quantification linearised plasmid containing the PCR product was diluted to concentrations between $4.5 \times 10^{-16} \mathrm{~mol}$ and $2 \times 10^{-22} \mathrm{~mol}$ and PCR performed for the cycle number at which $50 \%$ of the samples 
Table 1 Characteristics of subjects in the three study groups

\begin{tabular}{|c|c|c|c|c|c|c|c|c|}
\hline & $\begin{array}{l}\text { Sex } \\
(M: F)\end{array}$ & $\begin{array}{l}\text { Age } \\
\text { range (years) }\end{array}$ & Atopy & $\begin{array}{l}\text { Inhaled } \\
\text { steroids }\end{array}$ & $\begin{array}{l}W C C \\
\left(\times 10^{-9} / l\right)\end{array}$ & $\begin{array}{l}\text { Eosinophils } \\
\left(\times 10^{-9} / l\right)\end{array}$ & $\begin{array}{l}I g E \\
(I U / l)\end{array}$ & $\begin{array}{l}F E V_{1} \\
\text { (\% predicted) }\end{array}$ \\
\hline $\begin{array}{l}\text { Normal } \\
\text { subjects } \\
(\mathrm{n}=7)\end{array}$ & $7: 0$ & $26-38$ & No & No & 5.99 & 0.08 & $\begin{array}{l}61 \\
(14-176)\end{array}$ & 105 \\
\hline $\begin{array}{l}\text { Atopic } \\
\text { asthma } \\
(n=6)\end{array}$ & $3: 3$ & $28-64$ & Yes & Yes & 6.40 & 0.188 & $\begin{array}{l}219 \\
(23-643)\end{array}$ & 103 \\
\hline $\begin{array}{l}\text { Cystic } \\
\text { fibrosis } \\
(n=10)\end{array}$ & $8: 2$ & $24-30$ & 1 yes $/ 9$ no & 2 yes $/ 8$ no & 13.65 & 0.216 & $\begin{array}{l}53 \\
(6-3339)\end{array}$ & 62 \\
\hline
\end{tabular}

$\mathrm{WCC}=$ white cell count; $\mathrm{FEV}_{1}=$ forced expiratory volume in one second.

were first positive in each group. The concentration of product was determined by the lowest concentration that produced a visible band. This gave a measure of the minimum amount of mRNA for each of the products assuming approximately equivalent reverse transcription prior to the PCR. For those groups where less than $50 \%$ of samples were positive at 35 cycles, PCR of the concentration series was performed for 35 cycles and the starting template estimated to be less than the lowest concentration visible on the gel at 35 cycles.

\section{Results}

All subjects had a full blood count and serum IgE level performed at the same time that their blood was taken for RNA extraction. Group characteristics for age, sex, atopic status, inhaled corticosteroid use, blood counts, IgE level, and lung function are summarised in table 1 .

The proportions of samples in each group positive for COX-1, COX-2, FLAP, and 15LO remained constant with increasing cycle number. COX-1 mRNA was detected in polymorphs and mononuclear cells from normal subjects and from patients with asthma and cystic fibrosis. By 35 cycles there was an approximately threefold greater number of transcripts in polymorphs from both asthmatic $(88 \%)$ and cystic fibrosis $(75 \%)$ patients compared with normal subjects (33\%) (fig 3A). In contrast, increased levels of COX-1 transcripts were seen only in the asthmatic patients when measured in mononuclear cells. COX-2 transcripts were not detected in polymorphs or mononuclear cells of any patients with cystic fibrosis (fig 3B). In comparison, COX-2 mRNA transcripts were detected in polymorphs from $20 \%$ of normal subjects and $50 \%$ of asthmatic subjects; $25 \%$ of normal subjects expressed COX-2 mRNA in mononuclear cells compared with undetectable levels in asthmatic patients.

By 27 cycles 5-LO mRNA was detected in approximately $30 \%$ of mononuclear cells and polymorphs from both normal and asthmatic subjects (fig 4A). This basal level of expression was much reduced in patients with cystic fibrosis in whom only $16 \%$ expressed $5-\mathrm{LO}$ in mononuclear cells and none in polymorphs. At 25 cycles FLAP mRNA could be detected in more than $50 \%$ of mononuclear cells and polymorphs from both normal and asthmatic subjects but it was completely absent in both cell types from patients with cystic fibrosis (fig 4B). There was no difference in FLAP mRNA expression between asthmatic and normal subjects in polymorphs $(62 \%)$ but an increased level of FLAP mRNA was detected in mononuclear cells of asthmatic patients (75\%) compared with normal subjects $(40 \%)$.

By 33 cycles 15-LO was not detectable in any of the patients with cystic fibrosis in either cell type (fig 4C). Transcripts were detected in approximately $10 \%$ of mononuclear cells from normal and asthmatic subjects and in polymorphs from normal subjects. In contrast, there was a significant increase in 15-LO in the polymorphs isolated from asthmatic patients (75\%).

When PCR analysis was continued to 35 cycles it was possible to detect mRNA in cells at lower concentrations (table 2). Products not detected at 35 cycles suggested that the cDNA sample contained less than 0.002 attomoles
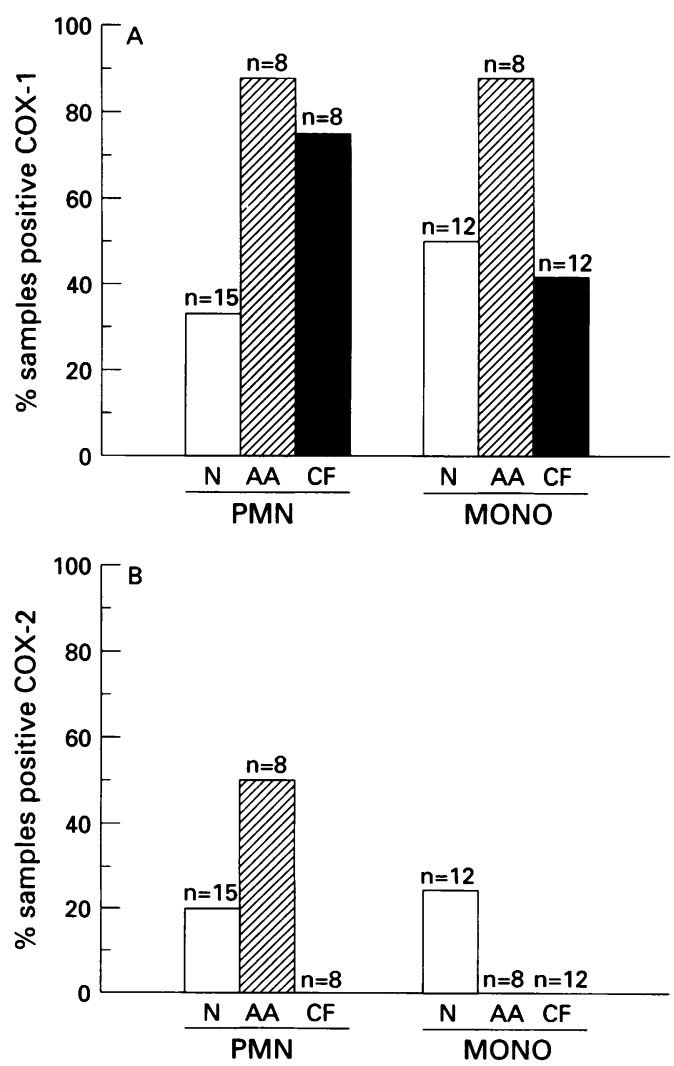

Figure 3 Comparison of the number of samples positive for (A) COX-1 and (B) COX-2 in normal subjects (N) and patients with atopic asthma (AA) and cystic fibrosis (CF) at 35 cycles. PMN = polymorphonuclear cells; MONO= mononuclear cells. 

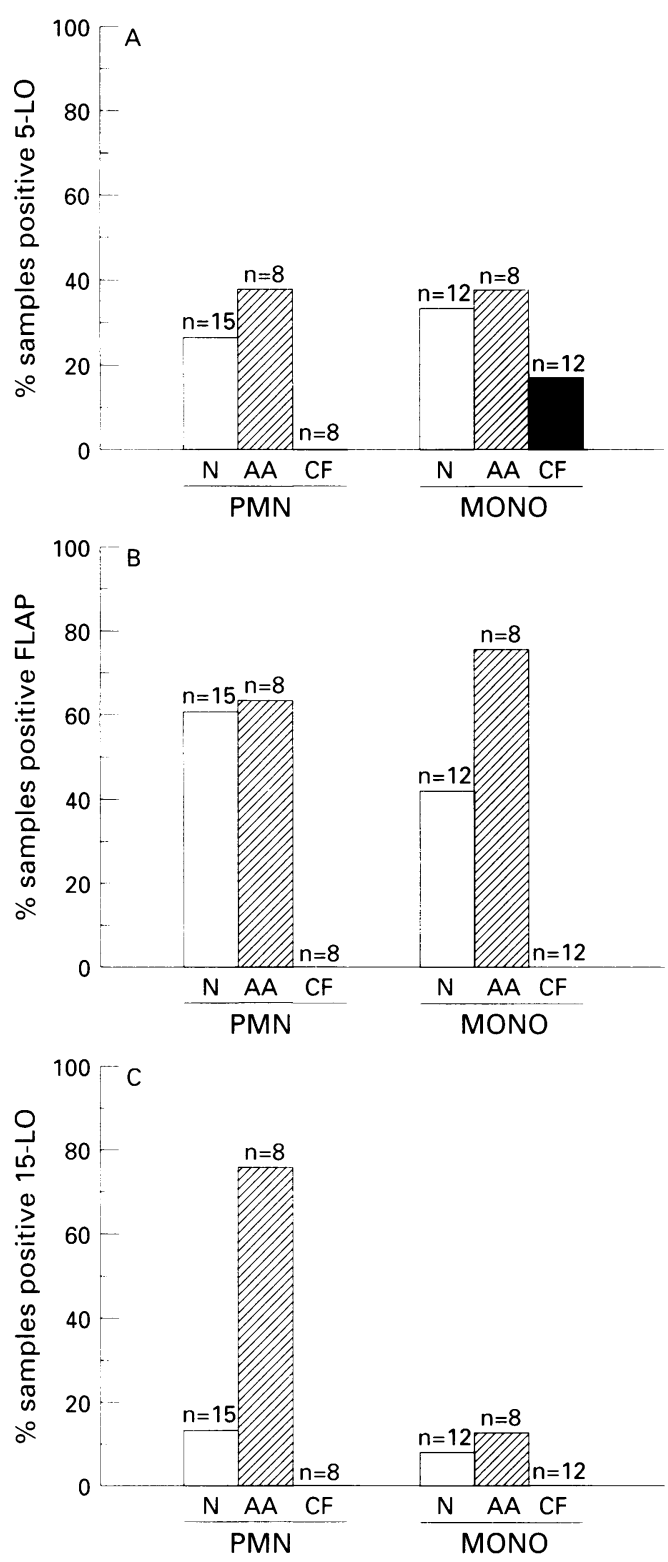

Figure 4 Comparison of the number of samples positive for (A) 5-LO at 27 cycles, (B) FLAP at 25 cycles, and (C) 15-LO at 33 cycles in normal subjects (N) and patients with atopic asthma $(A A)$ and cystic fibrosis (CF). PMN = polymorphomuclear cells; $M O N O=$ mononuclear cells.

$\left(2 \times 10^{-21}\right.$ mole or approximately 1500 copies of $\mathrm{cDNA}$ ) which was less than one transcript per 10000 cells and therefore considered as not present. After 35 cycles the level of 5-LO mRNA was greater in polymorphs from both asthmatic and cystic fibrosis patients compared with normal subjects, whereas there was no difference in 5-LO mRNA in mononuclear cells

Table 2 Cumulative percentage of samples positive by 35 cycles for COX-1, COX-2, 5$L O, F L A P$, and 15-LO in normal subjects and patients with atopic asthma and cystic fibrosis in peripheral blood polymorphonuclear cells and mononuclear cells

\begin{tabular}{|c|c|c|c|c|c|c|}
\hline & \multicolumn{3}{|c|}{ Polymorphonuclear cells } & \multicolumn{3}{|c|}{ Mononuclear cells } \\
\hline & Normal & $\begin{array}{l}\text { Atopic } \\
\text { asthma }\end{array}$ & $\begin{array}{l}\text { Custic } \\
\text { fibrosis }\end{array}$ & Normal & $\begin{array}{l}\text { Atopic } \\
\text { asthma }\end{array}$ & $\begin{array}{l}\text { Cystic } \\
\text { fibrosis }\end{array}$ \\
\hline COX-1 & 33 & 87.5 & 75 & 50 & 87.5 & 41.6 \\
\hline $\mathrm{COX}-2$ & 20 & 50 & 0 & 25 & 0 & 0 \\
\hline 5-LO & 40 & 62.5 & 62.5 & 58 & 50 & 50 \\
\hline FLAP & 93.3 & 75 & 87.5 & 91.6 & 100 & 100 \\
\hline $15-\mathrm{LO}$ & 40 & 75 & 0 & 25 & 25 & 0 \\
\hline
\end{tabular}

between any of the groups. FLAP mRNA was detected in most samples from polymorphs and mononuclear cells in all the subject groups. There was increased expression $(75 \%)$ of 15 LO mRNA in polymorphs from asthmatic subjects compared with normal subjects $(40 \%)$. This difference was not present in mononuclear cells. 15-LO was not detected in either polymorphs or mononuclear cells from patients with cystic fibrosis.

Semi-quantitation of each of the cDNA products confirmed that detection at higher cycle numbers corresponded to less starting template (table 3). All transcripts were less abundant than GAPDH, with 5-LO and FLAP being 10-100 times less and COX-1, COX-2, and 15-LO 100000 to one million times less abundant. The amounts of 5-LO and FLAP were similar in all three groups, and 15-LO was 1000 times more abundant in polymorphs from asthmatic subjects than in any other group. COX-1 transcripts were more abundant in asthmatic subjects than in normal subjects or patients with cystic fibrosis, and the number of COX-2 transcripts was marginally greater in polymorphs from asthmatic subjects than in other groups.

\section{Discussion}

In this study we examined the basal expression of the mRNA for the enzymes involved in the production of eicosanoid mediators in normal subjects and compared this with two diseases characterised by chronic airway inflammation. We were able to detect increased transcripts of COX-1 mRNA in polymorphonuclear cells and in mononuclear cells of atopic asthmatics when compared with normal subjects. COX-2, in contrast, was increased only in polymorphs from asthmatic subjects when compared with normal subjects and patients with cystic fibrosis. 5-LO transcripts were similar in all three groups, as were FLAP mRNA transcripts. 15LO mRNA transcripts were increased in the polymorph fraction of patients with atopic asthma.

A semi-quantitative approach to PCR using known concentrations of our PCR products was used to enable a comparison between normal subjects and patients with two inflammatory diseases. More accurate quantitation to the level of determining copies of mRNA per cell was possible but would have been extremely time consuming with the number of samples generated. The semi-quantitation confirmed the results of the serial sampling in that the later appearance of product correlated with lower concentrations of starting cDNA template and therefore less mRNA. Examination of the enzymes involved in leukotriene production showed that the mRNA for both 5-LO and FLAP was abundant. There was no difference between the 5-LO and FLAP mRNA levels seen in normal subjects and patients with asthma, therefore increased transcription does not explain the increased production of leukotrienes in asthmatic patients. This suggests that control of leukotriene production may be post-transcriptional. In contrast, during differ- 
Table 3 Relative concentrations of starting cDNA template for GAPDH, COX-1, COX-2, 5-LO, FLAP, and 15-LO, based on a concentration series of the cloned product, in normal subjects and patients with atopic asthma and cystic fibrosis in peripheral blood polymorphonuclear and mononuclear cells

\begin{tabular}{|c|c|c|c|c|c|c|}
\hline & \multicolumn{3}{|c|}{ Polymorphonuclear cells } & \multicolumn{3}{|l|}{ Mononuclear cells } \\
\hline & Normal & $\begin{array}{l}\text { Atopic } \\
\text { asthma }\end{array}$ & $\begin{array}{l}\text { Cystic } \\
\text { fibrosis }\end{array}$ & Normal & $\begin{array}{l}\text { Atopic } \\
\text { asthma }\end{array}$ & $\begin{array}{l}\text { Cystic } \\
\text { fibrosis }\end{array}$ \\
\hline $\begin{array}{l}\text { GAPDH } \\
\text { COX-1 } \\
\text { COX-2 } \\
5-L O \\
\text { FLAP } \\
15-L O\end{array}$ & $\begin{aligned} & 5\left(\times 10^{-17}\right) \\
< & 5\left(\times 10^{-22}\right) \\
< & 2.6\left(\times 10^{-22}\right) \\
< & 2\left(\times 10^{-18}\right) \\
& 2\left(\times 10^{-18}\right) \\
< & 3\left(\times 10^{-22}\right)\end{aligned}$ & $\begin{array}{l}2.5\left(\times 10^{-16}\right) \\
2.5\left(\times 10^{-21}\right) \\
2.6\left(\times 10^{-22}\right) \\
2\left(\times 10^{-18}\right) \\
2\left(\times 10^{-18}\right) \\
2\left(\times 10^{-19}\right)\end{array}$ & $\begin{aligned} & 2.5\left(\times 10^{-17}\right) \\
& 5\left(\times 10^{-22}\right) \\
&<2.6\left(\times 10^{-22}\right) \\
& 2\left(\times 10^{-18}\right) \\
& 2\left(\times 10^{-19}\right) \\
&<3\left(\times 10^{-22}\right)\end{aligned}$ & $\begin{aligned} & 5\left(\times 10^{-17}\right) \\
& 5\left(\times 10^{-22}\right) \\
&<2.6\left(\times 10^{-22}\right) \\
& 2\left(\times 10^{-18}\right) \\
& 4.5\left(\times 10^{-19}\right) \\
&<3\left(\times 10^{-22}\right)\end{aligned}$ & $\begin{array}{r}2.5\left(\times 10^{-16}\right) \\
2.5\left(\times 10^{-20}\right) \\
<2.6\left(\times 10^{-22}\right) \\
2\left(\times 10^{-17}\right) \\
2\left(\times 10^{-18}\right) \\
<3\left(\times 10^{-22}\right)\end{array}$ & $\begin{array}{rl} & 2.5\left(\times 10^{-18}\right) \\
<5 & 5\left(\times 10^{-22}\right) \\
< & 2.6\left(\times 10^{-22}\right) \\
2 & \left(\times 10^{-18}\right) \\
2 & \left(\times 10^{-19}\right) \\
< & 3\left(\times 10^{-22}\right)\end{array}$ \\
\hline
\end{tabular}

entiation of HL-60 cells by DMSO the amount of 5-LO transcript is increased but there is no post-translational modification of the enzyme, no increase in transcription following stimulation with calcium ionophore, and no loss of cytosolic enzyme following nuclear translocation. ${ }^{1516}$ If the enzyme can be "recycled" there would be less need for large amounts of its mRNA transcript. Evidence for this has been described in mast cells following antigenic stimuli. ${ }^{17}$ The levels of 5-LO and FLAP mRNA transcripts we have found are in keeping with studies that suggest that the expression in peripheral blood cell monocytes is low and increases dramatically once they become macrophages, together with increased production of eicosanoids. ${ }^{18-20}$ Migration of polymorphs to the inflammatory site and their activation may result in a similar upregulation of 5-LO and FLAP expression and increased production of leukotrienes.

In contrast, in patients with cystic fibrosis the mRNA for all the enzymes was detected later and reflects the slightly lower concentrations of the starting template. Similar results for 5-LO and FLAP were obtained, however. This is in contrast to the increased levels of leukotrienes found in the sputum of patients with cystic fibrosis who have high levels of leukotrienes even when "well" between acute infective exacerbations. ${ }^{2122}$ This again suggests post-transcriptional control of leukotriene production in peripheral blood cells in patients with cystic fibrosis.

There were clear differences between the expression of mRNA for COX-1 and COX2 in mononuclear cells and polymorphs. As expected, the "constitutive" form of cyclo-oxygenase, COX-1, was detected in most samples. More samples were positive in the two disease groups than in the normal subjects. Although COX-1 levels are thought to be stable, several studies have suggested that serum stimulatory factors are capable of upregulating COX-1 expression, and this may explain the increased expression in these two inflammatory diseases. ${ }^{23}$ In contrast, more COX-2 was detectable in the polymorphs of asthmatic patients, but no COX-2 was detected in patients with cystic fibrosis and it was found in only $20-25 \%$ of normal subjects. The lack of detectable COX-2 in all patients with asthma and cystic fibrosis was somewhat surprising, given the inflammatory nature of their illness, although these patients had been chosen while stable. Inhibitory feedback of further prostaglandin production or post-transcriptional con- trol of prostaglandin production such as activation of protein kinase $\mathrm{C}$ to divert eicosanoid production may be responsible. ${ }^{24} \mathrm{Al}-$ ternatively, the absence of detectable COX-2 in peripheral blood cells may be due to their lack of activation or differentiation into macrophages, since tissue macrophages express more COX -2 and produce more prostaglandins. ${ }^{25}$

15-LO was detected in increased amounts in polymorphs from asthmatic patients. Eosinophil-enriched leucocyte preparations contain 15-LO whilst immunofluorescence studies have detected the protein only in eosinophils. ${ }^{2627}$ Thus, increased amounts detected in the polymorph fraction in our study in asthmatic subjects are likely to be due to eosinophils. Although our experimental technique did not allow us to determine the amount of 15-LO per million eosinophils, the 1000 times greater amount of 15-LO in polymorphs from asthmatic subjects is greater than would be expected given that the eosinophil count in normal subjects was $0.08 \times 10^{-9} / 1$ and in asthmatic subjects was $0.188 \times 10^{-9} / 1$.

At present there is little information available on stimuli that regulate $15-\mathrm{LO}$ expression. In peripheral blood mononuclear cells of normal volunteers the cytokines IL-4 and IL-13 upregulate $15-\mathrm{LO}$ mRNA, enzyme and products, and hydrocortisone reduces it. ${ }^{2829}$ It has been suggested that $15-\mathrm{LO}$ is an effector molecule for IL-4. ${ }^{30}$ In addition, several immunohistochemistry studies have demonstrated 15LO enzyme in normal, bronchitic and asthmatic airways, predominantly in airway epithelial cells and in eosinophils in the submucosa. ${ }^{2731}$ The greatest staining was seen in asthmatic airways. It is tempting to postulate that the increase in $15-\mathrm{LO}$ in asthma is in response to the chronic inflammation - an attempt to limit the inflammation and aid resolution. In an experimental glomerulonephritis model elevated levels of 15-LO are associated with a reduction in pro-inflammatory mediators such as leukotrienes, and with resolution of the renal lesions. ${ }^{32}$

The absence of 15-LO in peripheral blood cells in cystic fibrosis is therefore puzzling. It is possible that there is a defect in the antiinflammatory response leading to a loss of 15LO. In bronchial epithelial cells from patients with cystic fibrosis there is evidence that the anti-inflammatory cytokine IL-10 is downregulated. ${ }^{33}$ However, given the abundant inflammatory response in the lung in cystic fibrosis, it is equally possible that $15-\mathrm{LO}$ is present and upregulated, but limited to ac- 
tivated cells such as the eosinophil and alveolar macrophage already in the lung. The peripheral blood cells sampled would therefore not be representative of activated cells, hence the lower levels of 15-LO expressed. Clearly, further work is needed to answer these questions.

The patients in this study were specifically chosen to be on low dose inhaled corticosteroids to minimise any effect they might have on the expression of these enzymes. The plasma level of corticosteroids in these patients is likely to be extremely low. While the effect of corticosteroids on 5-LO is controversial, and on 15LO unknown, they do downregulate COX-2 expression. ${ }^{3}$ An effect on COX-2 expression cannot be excluded and, if present, would underestimate the increase in COX-2 in these inflammatory diseases.

In summary, by using semi-quantitative PCR to compare basal levels of mRNA for the enzymes involved in eicosanoid production we have been able to demonstrate that there is little difference in 5-LO and FLAP expression between normal subjects and patients with atopic asthma and cystic fibrosis, whereas COX-1, COX-2 and 15-LO are increased in asthmatic patients and COX-2 and 15-LO were undetectable in patients with cystic fibrosis. This suggests that the level of control of eicosanoid production varies considerably between pathways and involves predominantly post-transcriptional mechanisms.

The authors would like to thank Dr Duncan Empey and Ms Glenda Esmond for providing access to cystic fibrosis patients from their clinic, and also all the patients who agreed to participate in this research.

1 Lewis RA, Austen KF, Soberman RJ. Leukotrienes and other products of the 5 -lipoxygenase pathway. $N$ Engl $\mathscr{F}$
Med 1990;323:645-55.

2 Arm JP, Lee TH. Sulphidopeptide leukotrienes in asthma (editorial review). Clin Sci 1993;84:501-10.

3 O'Banion MK, Winn VD, Young DA. cDNA cloning and functional activity of a glucocorticoid-regulated inflammatory cyclooxygenase. Proc Natl Acad Sci USA 1992 89:4888-92.

4 Mitchell JA, Larkin S, Williams TJ. Cyclooxygenase-2: regulation and relevance in inflammation. Biochem Pharmacol 1995;50:1535-42.

5 Christie PE, Spur BW, Lee TH. The effects of lipoxin A4 on airway responses in asthmatic subjects. Am Rev Respir Dis 1992;145:1281-4.

6 Serhan CN. Lipoxin biosynthesis and its impact in in flammatory and vascular events. Biochim Biophys Acta flammatory and

7 Fischer DB, Christman JW, Badr KF. Fifteen-S-hydroxyeicosatetraenoic acid (15-S-HETE) specifically antagonises the chemotactic action and glomerular synthesis of leukotriene B4 in the rat. Kidney Int 1992;41:1155-60.

8 Serhan CN. Lipoxins: eicosanoids carrying intra- and intercellular messages. $\mathcal{F}$ Bioenerg Biomembr 1991;23:105-22.

9 Miadonna A, Tedeschi A, Brasca C, Folco G, Sala A Murphy RC. Mediator release after endobronchial antigen challenge in patients with respiratory allergy. $\mathcal{F}$ Allergy Clin Immunol 1990;85:906-13.
10 Sampson AP, Green CP, Spencer DA, Piper PJ, Price JF Leukotrienes in the blood and urine of children with acute asthma. Ann NY Acad Sci 1991;629:437-9.

11 Sampson AP, Thomas RU, Costello JF, Piper PJ. Enhanced leukotriene synthesis in leukocytes of atopic and asthmatic subjects. Br f Clin Pharmacol 1992;33:423-30.

12 Lee TH, Crea AEG, Gant V, Spur BW, Marron BE, Nicolaou KC, et al. Identification of lipoxin $\mathrm{A} 4$ and its relationship to the sulfidopeptide leukotrienes $C 4, D 4$, $\mathrm{E} 4$ in the bronchoalveolar lavage fluids obtained from patients with selected pulmonary diseases. Am Rev Respir Dis 1990;141:1453-8.

13 Israel E, Rubin P, Kemp JP, Grossman J, Pierson W, Siegel $\mathrm{SC}$, et al. The effect of inhibition of 5-lipoxygenase by zileuton in mild-to-moderate asthma. Ann Intern Med 1994;119:1059-66.

14 Gough NM. Rapid and quantitative preparation of cytoplasmic RNA from small numbers of cells. Anal Biochen 1988;173:93-5.

15 Bennett CF, Chiang M-Y, Monia BP, Crooke ST. Regulation of 5-lipoxygenase and 5-lipoxygenase activating protein expression in HL-60 cells. Biochem f 1993;289:33-9.

16 Kargman S, Rouzer CA. Studies on the regulation, biosynthesis, and activation of 5-lipoxygenase in differentiated HL60 cells. $\mathcal{F}$ Biol Chem 1989;264:13313-20.

17 Malaviya R, Jakschik BA. Reversible translocation of 5 ipoxygenase in mast cells upon $\mathrm{IgE} /$ antigen stimulation. f Biol Chem 1993;268:4939-44.

18 Coffey MJ, Wilcoxen SE, Peters-Golden M. Increases in 5-lipoxygenase activating protein account for enhanced capacity for 5-lipoxygenase metabolism that accompanies differentiation of peripheral blood monocytes into alveola macrophages. Am 7 Respir Cell Mol Biol 1994:11:153-8.

19 Pueringer RJ, Bahns CC, Hunninghake GW. Alveolar macrophages have greater amounts of the enzyme 5 lipoxygenase than do monocytes. F Appl Physiol 1992;73. $781-6$.

20 Bigby TD, Holtzman MJ. Enhanced 5-lipoxygenase activity from lung macrophages compared to monocytes from from lung macrophages compared to monocyte

21 Zakrzewski JT, Barnes NC, Piper PJ, Costello JF. Detection of sputum eicosanoids in cystic fibrosis and in normal aliva by bioassay and radioimmunoassay. Br f Pharmaco 1987;23:19-27.

22 Sampson AP, Spencer DA, Green CP, Piper PJ, Price JF Leukotrienes in the sputum and urine of cystic fibrosis children. Br f Clin Pharmacol 1990;30:861-9.

23 Lin AL, Bienkowski MJ, Gorman RR. Regulation of prostaglandin $\mathrm{H}$ synthase mRNA levels and prostaglandin biosynthesis by platelet-derived growth factor. $\mathcal{F} \mathrm{Biol}$ Chen 1989;264:17379-83.

24 Ali A, Ford-Hutchinson AW, Nicholson DW. Activation of protein kinase $\mathrm{C}$ down-regulates leukotriene $\mathrm{C} 4$ synthase an eosinophilic substrain of HL-60 cells. F Immunol 1994 153:776-88.

25 Hempel SL, Monik MM, Hunninghake GW. Lipopolysaccharide induces prostaglandin $\mathrm{H}$ synthase- 2 protein and mRNA in human alveolar macrophages and blood monocytes. $f$ Clin Invest 1994;93:391-6.

26 Sigal E. The molecular biology of mammalian arachidonic acid metabolism. Am f Physiol 1991;260:L13-28.

27 Nadel JA, Conrad DJ, Ueki IF, Schuster A, Sigal E. Immunocytochemical localisation of arachidonate 15-lipoxygenase in erythrocytes, leukocytes, and airway cells. Clin Invest 1991;87:1139-45.

28 Conrad DJ, Kuhn H, Mulkins M, Highland E, Sigal E. Specific inflammatory cytokines regulate the expression of human monocyte 15-lipoxygenase. Proc Natl Acad Sci USA 1992;89:217-21.

29 Nassar GM, Morrow JD, Roberts II LJ, Lakkis FG, Badr $\mathrm{KF}$. Induction of 15-lipoxygenase by interleukin-13 in human blood monocytes. $\mathcal{F}$ Biol Chem 1994;269:27631-4

30 Sigal E, Conrad DJ. Human 15-lipoxygenase: a potential effector molecule for interleukin-4. Adv Prostaglandin Thromboxane Leukot Res 1994;22:309-16.

31 Shannon VR, Chanez P, Bousquet J, Holtzman MJ. Histochemical evidence for induction of arachidonate 15-lipoxygenase in airway disease. Am Rev Respir Dis 1993;147: $1024-8$

$32 \mathrm{Badr}$ KF. 15-lipoxygenase products as leukotriene antgonists: therapeutic potential in glomerulonephritis. Kidney Int 1992;42(Suppl 38):S101-8.

33 Bonfield TL, Konstan MW, Burfeind P, Panuska JR, Hilliard JB, Berger $M$. Normal bronchial epithelial cells constitutively produce the anti-inflammatory cytokine interleukin-10, which is downregulated in cystic fibrosis. $A m$ f Respir Cell Mol Biol 1995;13:257-61. 